\author{
ALEXANDER ROCKLIN
}

\title{
IMAGINING RELIGIONS IN A TRINIDAD VILLAGE: THE AFRICANITY OF THE SPIRITUAL BAPTIST MOVEMENT AND THE POLITICS OF COMPARING RELIGIONS
}

\author{
Involved stuff, this, with so many different strands tangled into it that \\ one almost despairs of getting it straightened out.
}

Melville Herskovits, “Trinidad Field Trip Diary,” July 28, $1939^{1}$

The question of "origins" is always a politically fraught one. ${ }^{2}$ Looking through the historical evidence available it is unclear where and how Trinidad's Spiritual Baptists emerged as a religious movement, the evidence being particularly inconclusive before the "Shouters" were outlawed in 1917. Though they are now recognized as a religion, it was not always so, since the question of whether or not their practices counted as "religion" was tied up with the question of their legal status and their very recognition and formation as a "religion" (as the colonial regime understood that). The question of the Africanity of Spiritual Baptist practice, while it, too, may now seem to be self-evident

1. The Herskovits papers are held at the Schomburg Center for Research in Black Culture, New York Public Library. The materials related to the Trinidad trip are contained in boxes 15 through 17. Box 15 Folder 82 holds the "Trinidad Field Trip Diary," herein referred to as "Diary." Folder 87 holds "Trinidad Notes Book I Toco" June to July 1939. Folder 88 holds "Trinidad Notes Book II Toco" July to August 1939. In Box 16, Folder 89 holds "Trinidad Notes Book III" September 1939. The notebooks will be referred to herein as "Notes," followed by the book number.

2. Earlier drafts of this paper were presented at the Caribbean Studies Workshop and the "Problems in the History of Religions" seminar at the University of Chicago and I benefited greatly from the comments and critique of those in attendance. Thanks to the librarians at the New York Public Library's Schomburg Center for Research in Black Culture for all their help. Thanks to Wendy Doniger and Stephan Palmié for their comments, criticism, and help with editing. I would also like to thank the two anonymous reviewers for their thoughtful readings.

New West Indian Guide / Nieuwe West-Indische Gids vol. 86 no. 1 \& 2 (2012):55-79 
to many in Trinidad, ${ }^{3}$ was also not always so. The widespread acceptance of the self-evidence of their Africanity was probably only possible after the Black Power movement of the 1970s in Trinidad and Tobago. It also probably owes something to the 1939 ethnography Trinidad Village, a study of the village Toco focusing on Spiritual Baptist groups in the area by anthropologists Frances and Melville Herskovits, the thesis of which was the primacy, despite significant reworkings and reinterpretations, of the groups' Africanity. ${ }^{4}$

The Herskovitses' work over the years had largely been dedicated to debunking what M. Herskovits called "the myth of the Negro past," which is the title of his now classic 1941 work. At the time when Melville Herskovits began working in the 1920s, the notion that African Americans had a unique culture of their own, and that that culture had significant continuities with the cultures of West and Central Africa, was radical for mainstream American scholarship. The Herskovitses' studies of the cultures of peoples of African descent in the Americas (in Suriname, Haiti, Trinidad, and Brazil) served as part of this larger project to uncover the African past of African Americans, to recover the continuity (and at times to show the identity) of African American culture with an African one. With this they hoped to help restore the standing and dignity of black Americans. While Melville Herskovits had problematic relationships with African American scholars who were also studying the histories and cultures of peoples of African descent (see Gershenhorn 2004:93-121), and despite critiques of the Herskovitses' work over the last thirty-five years or so (see Mintz \& Price 1992, Price \& Price 2003, and Scott 1991), their influence on anthropology continues to this day and their work was undoubtedly important for the beginnings of the anthropology of African American cultures, African studies, and African American Studies in the United States. ${ }^{5}$

In Trinidad, the Spiritual Baptists became another test case for this project. The Herskovitses tell the reader that they found among their Trinidadian informants a general indifference (and at times hostility) to Africa and to their proposal of an African origin for African Trinidadian culture (Trinidad Village, hereafter TV, 23). Going back to the Herskovitses' notes on their fieldwork in Trinidad and looking at their sources, however, one can see

3. The yearly supplements in most Trinidad newspapers celebrating Spiritual Baptist Shouter liberation day show the degree to which the Spiritual Baptists have arrived as a recognized Trinidadian religion, whose African origins are oft asserted.

4. The anthropologist Stephen Glazier's (1983:34) Spiritual Baptist informants told him, during his fieldwork in the late 1970s and early 1980s, that "Trinidad has one of the oldest and 'purest' traditions of African religion in the New World - sometimes citing Herskovits or Andrew Carr to that effect."

5. Their work, although pioneering for Euro-American scholarship, was hardly unique, being preceded by Caribbean and Latin American anthropologists and ethnologists with similar interests in the African diaspora in the Americas (Yelvington 2001:229). 
that responses to questions about the origins of Trinidadian religious discourse and practice (and about "Shouter" Baptists in particular) were more variegated and contentious than simple "indifference," or even hostility. In the context of the British Empire one hundred years after the end of slavery, where Africanity, most importantly for those in power, equaled barbarity and was viewed as a threat to the civil order, comparing the practices of a group like the "Shouter" Baptists to African religion, and at the same time, through that comparison, postulating a continuity and a kind of essential identity with African culture, would have been troubling to some. The Herskovitses' questions of African origins struck chords in a larger web of contestations over the colonial definition, illegalization, and repression of certain religious practices and communities on the island, including obeah ("African witchcraft") and the so-called Shouters. Who was answering questions, in what context, who was listening, and what may have been at stake varied, and so, therefore, did the answers given and the kinds of comparisons made.

Further, what the Herskovitses found in Trinidad was far more complex than the African "cultural retentions" for which they were searching. A few of their sources did embrace Africa, at times quite enthusiastically (though not necessarily in the same ways as they do today), to which the Herskovitses at times showed their own indifference, because the Africa imagined by some Trinidadians was not the Africa the anthropologists were in search of. While their identification of African cultural sources for Spiritual Baptist practice was useful, their Africanist filter caused the Herskovitses to over-emphasize Africanity, and underemphasize or ignore other resources which the Spiritual Baptists used in their social-formative labors, including European magic, fraternal organizations, Hinduism, and Islam. A close reading of the Herskovitses' monograph, field notes, and diary shows clearly that it was not simply that the people in the village where they worked were indifferent to Africa (though they did at times demur at Africa, for various reasons, as I will explore in the following), but that they had other interests, such as mail-order magic catalogues or the discourse and practices of Indian Trinidadian Hindus and Muslims. Ethnographies of contemporary Spiritual Baptist groups attest to similarly diverse interests and appropriations (see Duncan 2008, Glazier 1983, 1993, Zane 1999); they are evident in the Herskovitses' own field notes; and the kind of ingenuity ${ }^{6}$ which such interests and appropriations imply is evident through the history of African Trinidadian "shouting" groups, out of which the groups that are today identified as Spiritual Baptists most likely emerged. They are, however, underplayed or elided in Trinidad Village. Further, Trinidadians, drawing from a

6. When I use the term ingenuity I mean, with respect to the Spiritual Baptists, the ordinary ritual bricolage of poor people living in difficult conditions, drawing on whatever religious material was at hand for their own purposes. 
rich variety of cultural resources, proposed their own, differing origins for their religious practices, depending on what may have been at stake in their responses, given their context and position in Trinidadian society. Works by Sidney Mintz and Richard Price (1992) and Sally and Richard Price (2003) criticize the Herskovitses in part for setting out with the preset agenda of finding Africa in African American cultures and so, through that lens, inevitably finding Africa wherever they looked. They also criticize the Africa that they found for being static and homogenous, leading to essentializations and reifications on both sides of the Atlantic. Such critique remains valid for their work on Trinidad. The Trinidad case did suggest to the Herskovitses not the more straightforward continuities and retentions of African culture that they thought they had found elsewhere, but rather examples of what they called "transitions," "readaptations," and "reinterpretations" of and between African and European cultures. ${ }^{7}$ Rather than passive preservation, these terms compellingly suggest change, exchange, and synthesis. Such an interpretation of African Trinidadian culture, however, in some ways worked against the Herskovitses' project of recovering an authentic and essential African past on the island. So, despite the interesting theoretical heuristics that they proposed, the Herskovitses maintained that the processes of reinterpretation and readaptation helped to "retain the inner meanings of traditionally sanctioned modes of behavior while adopting new outer institutional forms" (TV vi). This allowed them to reintroduce passive retention and essentialization throughout their analysis of the Tocoans' practices, often through the metaphor of the culture's (changing, European) surface and (stable, African) depth, allowing Africa the central place of importance despite historical change and the dynamic practices of Trinidadians.

In the face of this gap between their theoretical perspective on the flux of culture and their insistence on deep permanence I want to read the Herskovitses with and against the Herskovitses. Rather than looking for retentions, cultural essences, or what David Scott (1991:263) calls an "authentic past," in order to understand the Trinidadian religious discourse and practice recorded in the Herskovitses' field writings, I will stay with the Herskovitses' suggestive terms "transition," "reinterpretation," and "readaptation," and with the sentiments and suggestions of the quotation from M. Herskovits with which I opened the paper: tentativeness, productive confusion, and radical contextuality brought out through his model of the many different "tangled strands." I would have "reinterpretation," then, suggest

7. The Herskovitses' ideas continually evolved throughout the 1930s, and their work in Trinidad was a particularly important moment for rethinking their ideas on "reinterpretation" as a theoretical category (Baron 2003). M. Herskovits (1952:553) would later extend "reinterpretation" in his Man and His Works, published in 1948, a year after Trinidad Village, to be a universal process of cultural change. 
what Stephan Palmié (2000:92) has called the "ackee and saltfish model of African American cultural history," which emphasizes ingenuity and change. Rather than take "readaptation" to be a process of the preservation or continuity of an inner "meaning" despite historical change, the "re-" in "readaptation" would suggest an ad hoc, unfinished quality to human social formation, a third- or fourth-hand repurposing in an ongoing process, without recourse to a privileged essence or a "deep" origin. And "transition" I will take as the in-flux state of culture, including religion, always ambivalent, contested, antagonistic, and heterogeneous.

Religion is a central feature of Trinidad Village. Over 40 percent of the Herskovitses' ethnography is made up of chapters specifically on "religion." The other chapters, on work, economy, class, the family, etc., are also sprinkled with "religious" material. Rather than taking religion to be a natural category, or an interior feeling or state which finds an outward expression, as the Herskovitses did, ${ }^{8}$ I want to ask, what gets to count as "religion," in what circumstances, according to whom, with what consequences, and what role does "Africa" (or other proposed origins) play in this discourse on religion in Trinidad? Following David Chidester's work on the history of comparative religion and colonialism in southern Africa, I will use the comparative work done in the conversations between the Herskovitses and subaltern comparativists (the villagers of Toco and its environs who were their "informants") as a window into the discourse on religion in Trinidad: the ongoing production of local knowledge about the origins, similarities, and differences of religions, defining and reifying religious groups as part of struggles for local control (Chidester 1996:2-4).

In the first section of the paper I will give some broader background for the discourse on religion in the colonial British Caribbean and will also consider the politics of the definition and prohibition of "Shouters" in Trinidad up to the time of the Herskovitses' arrival. In the remaining sections I will turn to the Herskovitses' unpublished field notes and diary from their Trinidad fieldtrip and look there at the fragments of conversations and fleeting voices of the Trinidadians with whom the Herskovitses spoke. In the second section I introduce the local politics of Africa and comparative religion through an analysis of the comparative work of two of the Herskovitses' earliest interlocutors, their maid Margaret Wright and her friend Selina Washington. In part three, I look to other origins that some Spiritual Baptists proposed to the Herskovitses for their practices, including Western Esotericism. And section

8. Melville Herskovits understood African American religion generally on a similar model to the one of surface and depth which the Herskovitses laid out in Trinidad Village. In The Myth of the Negro Past Herskovits portrays African Americans as essentially religious at their core, and argues that within their "deep" religious inclination, in the very depths of the "deep," one can find "Africa" (Herskovits 1990:207). 
four turns to the Spiritual Baptist leader Ethel Patrick, her embrace of Africa, and Spiritual Baptist cosmology, as a way of thinking through the other imagined Africas in circulation in Trinidad besides the Herskovitses' model. In the following, rather than indifference to connections with the religious practices of Africa, Europe, or anywhere else, I try to see what people were interested in, and what was at stake in emphasizing or marginalizing differences, similarities, or connections between postulated religions (or cultures more broadly), given who was speaking to whom in what context.

\section{JUMPING, SHAKING, SHOUTING}

In the Caribbean, the colonial definition of the practices of peoples of African descent as "religion" was tentative and erratic. In addition, Rosalind Shaw (1990:339) tells us that there are no exact translations of the word "religion" in the languages of the peoples of Africa. Africans did not divide up their lifeworlds as the British did, into the public secular and personal religious, with the focus in the latter on interiority and belief. In a sense then, before colonial contact there was no "religion" in Africa, as the British colonizers understood it. With the slave trade and colonization, however, people of African descent, like those from other parts of the British Empire, began to incorporate the categories and norms taken as natural by colonial administrations, to understand their lives, worlds, and practices through "religion." It is through this history of religion that the eventual formation and outlawing of the Spiritual Baptist movement, as well as the Herskovitses' later interventions, must be understood.

The British colonial elites in the Caribbean used the discourse of religion to regulate unfree laboring populations and other colonial subjects. Production of local knowledge on religions defined what practices got to count as "religion" and what practices did not. This included determining the nature and origin of such practices, as well as a (malleable and contested) hierarchy: revealed, true, natural, and pseudo-religions, as well as sects and, farther down the scale, idolatry, superstition, fetishism, and obeah (or witchcraft). Colonial officials' early questions about the religion of African slaves, however, largely concerned Christian proselytization, and only gradually did questions of what modern scholars might call traditional African religions arise, often in response to slave uprisings, such as Jamaica's Tacky's War of 1760.

If what the slaves were doing was not easily recognizable as "Christian" (as the British understood it, and the Spiritual Baptists were a borderline case, but for some so were Catholics), the practices of peoples of African descent were frequently said not to be religion at all. The discourse on Caribbean religions was part of larger projects of knowledge production about the Caribbean's inhabitants, which served as part of a repertoire of techniques used to manage 
and regulate slaves and other colonized peoples (later, indentured laborers and poor free people of color). As part of this discourse, the denial of religion amounted to a denial of full humanity, as Europeans understood it, thus justifying European colonization and exploitation. As will become clear later, this discourse became useful in the control and marginalization of Spiritual Baptists' meetings in the early twentieth century as well.

Europeans in the British Caribbean at first attempted to capture the diverse discourses and practices of African slaves under the category of "obeah" (African black magic), rather than the category of "religion." Even when what African Trinidadians were doing was arguably "Christian," however, when it was outside of white control and did not meet normative Protestant criteria of what religion was or ought to be, the attribution of "religion" was still denied, and religion's other, obeah, defined as riotous, superstitious, and African, remained as a subtext, helping to further delegitimize such practices. This was the mode of discourse that the colonial government of Trinidad and colonial elites eventually employed to suppress the various African Trinidadian Christian "shouting" groups that precede the Spiritual Baptist's emergence in the early twentieth century.

Tantalizing terms such as "shouting" and "jumping," while they have been read as evidence of the Spiritual Baptist movement before 1917 (sometimes as part of projects to recover an authentic past), are scant evidence for what was actually going on, and were clearly stereotyped language used in polemic against unruly or unregulated Afro-Christian groups. Because of the vagueness of these terms, it is easy to project the current group onto this past and read them forward to meet the interests of the present. But there is no evidence other than the words "Baptist," "shouting," and a suggestion of ritual ingenuity to indicate that these were the same groups as those analyzed by the Herskovitses. Neither Baptist missionary Edward Underhill's thin nineteenth-century description of these "jumping" and "shouting" Baptists, ${ }^{10}$ nor A.B. Huggins's work on the Merikin communities, suggests that these were Spiritual Baptists, with all that that name has come to mean.

The Spiritual Baptists' story first conclusively picks up not in Trinidad but with a prohibition ordinance in St. Vincent in the early twentieth century. In 1912 the colonial government of St. Vincent issued an ordinance meant "to render illegal the practices of 'Shakerism' as indulged in in the colony of St. Vincent" (Zane 1999:161). Before the prohibition, a St. Vincent police report from 1905 by the acting chief of police described the need to suppress "Shaker"

9. On obeah as a colonial discourse see Paton 2009.

10. See also as examples the Dominican Missionary Marie Bertrand Cothonay's (1893:157-

58) description of the practices of "black Baptists of Princes'-town," called "jumpers," and an article, "The Shouters," from The San Fernando Gazette and Trinidad News, May 19, 1894. 
Baptist groups in St. Vincent, "a matter which has its roots in one of the few distinct hereditary traits of African barbarism which still remains to the black race in St. Vincent" (quoted in Zane 1999:150). While the exact relationship between the St. Vincent "Shakers" and the Trinidad and Tobago "Shouters" is unclear, they appear to have much in common in terms of their practice (see Zane 1999). ${ }^{11}$ The "Shaker" prohibition shows that early justification for suppressing groups in St. Vincent (which were plausibly related to the Trinidadian Spiritual Baptists) involved tracing their origins to Africa and what was assumed to be Africa's inherent barbarism, but the language of the legal prohibition itself does not mention Africa. The colonial government of Trinidad took the Vincentian legislation as a model for their own prohibition when they outlawed "Shouter" meetings and "Shouter houses" in Trinidad in 1917.

The year of the Trinidad prohibition was the height of World War I in Europe. At home in Trinidad, labor agitations were on the rise. There were campaigns against the Indentured Labor scheme, which the war put an end to in the same year; and this in turn spurred the institution of a Habitual Idlers Ordinance, an antivagrancy law which allowed for the forced labor of "habitual idlers" on private estates (Singh 1994:12-14). It was in this tense climate, during which working-class African Trinidadians were beginning to organize and assert themselves, that the prohibition of this religion of mostly poor African Trinidadians was adopted.

During the legislative council hearings on Trinidad's "Shouters Prohibition Ordinance," the attorney-general located the origin of the "Shouters" in St. Vincent, where, he said, they had already been "legislated out of existence." He added that their practices were "not such as should be tolerated in a wellconducted community" (quoted in TV 342-43). Besides prohibiting the meeting of "Shouters" and the construction of "Shouter houses," the main charge of the prohibition seems to have been "indecency," which echoes the disparaging and sexually charged characterization of the "Shouter" meetings described in sensationalized news accounts before 1917. ${ }^{12}$ The Spiritual Baptists are today generally understood to be an Afro-Caribbean religious movement which draws most significantly from Protestant Christianity and African traditional religions (among others), and a distinct aspect of which is a ritual called "mourning ground," which features a period of seclusion, fasting, and the covering of the initiate's eyes with a kerchief, all of which is meant to induce visions, spirit travel, and "spiritual gifts." The prohibition itself, however, did not actually define what a "Shouter" was, and because it was a derogatory term, few charged under the prohibition would have called themselves

11. The "Shakers" were coming to Trinidad from St. Vincent to proselytize as early as 1894. See for example "The 'Shakers' in Town," The Port of Spain Gazette, July 4, 1894. 12. As an example see the article "Shouters" in The San Fernando Gazette and Trinidad News, May 19, 1894. 
"Shouters," but rather called themselves, for example, Independent Baptists, Apostolic Baptists, and Spiritual Baptists, among other names. What made one a "Shouter," then, was not immediately clear. ${ }^{13}$

During the discussion about the prohibition, a member of the legislature, Dr. Prada, asked whether there was any "book which describes the 'customs and practices of the body known as Shouters'?" The Inspector-General of Constabulary responded that his report described "the whole of the procedure." Dr. Prada then said: "I want to know how the Magistrate will be guided." The Attorney-General replied he will have to "call the police officer and decide. I take it the Shouters have not published a book of ritual." Dr. Prada: "You will have to get a high-caste Shouter to become a police officer" (the text reports parenthetically that there was laughter). ${ }^{14}$ The question of defining who a "Shouter" was and what "Shouters" did was left to the Magistrate, who would rely on the police. In a sense the police then were charged with doing the work of the comparative religionist, becoming experts on identifying what "Shouter" ritual involved. That members of the legislature were asking for a "Shouter" ritual manual that could be consulted in order to delineate and categorize "Shouter" groups and their practices is telling. This reflects Protestant British colonial assumptions that religions were self-evidently and naturally definable and separable, in large part on a textual basis. Religions were thought to produce books that consistently and coherently laid out the group's beliefs and rituals (the latter depending on the former). Since such texts defining the customary practice of Spiritual Baptists did not exist, it fell to the police to become the arbiters of custom as colonial anthropologists of religion.

Along this same line, the comment about recruiting a "high-caste Shouter" to become a resident police expert explicitly invokes British policy in India according to which Hindu and Muslim religious scholars were recruited as (in part government produced) authorities on their religious communities, charged with defining customary or personal laws for their groups, based on what were identified as the authoritative texts (such as the Laws of Manu for the Hindus). It was in part through this very process of the production and institutionalization of customary law, of cordoning off and defining officially recognized communities and their respective practices, that Hinduism and Islam were constructed, through the efforts of both colonizers and colonized elites, as "religions." What is evident here is the use of a model from India for thinking through the regulation of a non-Indian

13. Shouters Meeting Interrupted by Police," The Port of Spain Gazette, January 23, 1918; “Alleged Shouters' Meeting," The Trinidad Guardian, June 12, 1918; "Shouters' Meeting," The Port of Spain Gazette, July 19, 1920.

14. Hansard Records, Debates of the Legislative Council of Trinidad and Tobago, January-December 1917. November 16, 350-51, National Archives, Port of Spain. 
colonized population in the Caribbean. The colonial government in Trinidad was hoping to put in motion a similar process of definition and containment of the heterogeneous "Shouter" Baptist groups, to begin to rein them in under the sign of "religion." 15 A similar process of religion-making, through prohibition and police regulation and surveillance, as well as the hard struggle of legalization, recognition, and institutionalization, began to make the Spiritual Baptists, over many decades, a religion in this sense. The Herskovitses' work in 1939 took place in the midst of these processes of the congealing of the Spiritual Baptist movement, processes that continued long after they had left.

However, while the 1917 legislature wished that the Spiritual Baptists would act in a manner closer to their own understandings of what religion was or ought to be, nowhere did they refer to the movement as "religion," because the Spiritual Baptists did not meet normative colonial definitions of what religion was. Instead they called it a "sect or body" (quoted in TV 343). ${ }^{16}$ Further, the popular press largely delegitimized the "Shouters" and authorized their prohibition (despite any claims to freedom of religion) through denial of their status as a religion. For instance, reporting on the discussion of the ordinance in the Legislative Council, The Port of Spain Gazette, a mouthpiece for plantation owners, wrote that legislation had been introduced which was meant for the "elimination of the pseudo-religious body known locally as "The Shouters," who, they wrote, mistook "noise, enthusiasm, and shouting for religion." 17 The Shouter Prohibition Ordinance became law on November 28, 1917. While the struggle over local knowledge and control was being played out in part through colonial comparative religion, comparing and accounting for the origins of religions, it was not only a tool of the colonial officials or elites. The subaltern classes were actively engaged as well, and spoke back in the name of religion. This became evident some twenty years later, when the Herskovitses arrived in Trinidad.

15. At least by 1936, the Trinidad Constabulary Manual had a section on the "Shouters" which did enumerate the attributes which qualified a meeting as a "Shouter" meeting, including "Binding the head with white cloth," "Holding of lighted candles in the hands," "Ringing a bell at intervals during meetings," "Violent shaking of the body and limbs," "Shouting and grunting," "Flowers held in the hands of persons present," and "White chalk marks about the floor" (quoted in TV 345).

16. "Body" was a somewhat pejorative term used by the government of Trinidad in the nineteenth century to describe Dissenters and other non-Anglican Protestants living in the colony (e.g. "On Concurrent Endowment," Port of Spain Gazette, January 6, 1872).

17. Port of Spain Gazette, October 10, 1917. 


\section{COMPARING RELIGIONS IN A TRINIDAD VILLAGE}

While the Herskovitses argued that "retentions" were preserved through (or despite) the reinterpretations of African Trinidadian village dwellers, they wrote that the Trinidadians themselves were quite unaware of this African "presence" adhering in what they saw as their ordinary everyday practices. In Trinidad Village the Herskovitses told the reader in fact that Trinidadians, when it came to things African, felt indifference, particularly in comparison to other African American groups the Herskovitses had studied, in places like Suriname, Jamaica, and Haiti, who took pride in a postulated African heritage (TV 23). The Herskovitses' questions and interests, however, were not necessarily those of the villagers. This was particularly so in the case of the Spiritual Baptists, who were an outlawed minority under surveillance by the police and persecuted by the government, and for whom a comparison to Africa may have been problematic. But on reading the diary and field notes from the Trinidad trip, it is clear that not all of the people the Herskovitses spoke to in the village Toco were "indifferent" to Africa. On occasion some did choose to invoke Africa, as well as other kinds of origins, for their discourse and practice. The question becomes not one of simple disinterest, but of emphasizing or deemphasizing, of drawing attention to similarity or difference to African or any other culture, in a particular context, in the service of specific interests.

Melville and Frances Herskovits arrived in Trinidad and Tobago on June 14, 1939. That night, at a dinner for the newly knighted Chief Justice of Trinidad, their fellow diners suggested that the anthropologists should go to the village of Toco, in the far northeast of the island, because the south would be too difficult, owing to the "labor troubles" of the last three years, and because of "its intense industrialization" (Diary 1-6). ${ }^{18}$ The "troubles" that the Herskovitses were warned about were the immense and violent protests by laboring groups and unemployed masses that began in the mid-1930s and came to a head in 1937. The Herskovitses looked to do their work in a rural area, away from such unrest but also where African-derived culture, particularly the Afro-Trinidadian Shango cult, would still be available to them, evincing what they hoped would be fewer marks of European influence.

They were able to arrange for a place to stay in Toco and headed out to the village. M. Herskovits's first impressions of Trinidad recorded in his diary shows a dissonance between the anthropologists' expectations of what they would find and what they encountered in Toco. Early in the diary M. Herskovits wrote that he was impressed by "the smoothness of the Europeanized surface" of the African Trinidadian community in Toco (Diary 10). While they did not find "Africanisms" immediately in evidence, the Herskovitses used a metaphor of surface and depth, which appears in the

18. The diary appears to have been kept by Melville Herskovits alone. 
diary as well as their monograph, to relate what they saw as the relative positions and importance of European and African cultures. The Herskovitses were able to maintain their assertion of the central importance of African culture for African American lives by arguing that those aspects of Toco culture that had clear continuities with European cultures (of which there were quite a few) were in some sense superficial. The Spiritual Baptists and Shango, the Herskovitses argued, despite having varying aspects of European "surface," were rooted in "some of the most deeply set traditional values in Negro societies" (TV 189). The "deeply set" values in which these religions were rooted were of African origin.

On moving out to Toco, the Herskovitses hired Margaret Wright as their cook (Diary 6-8). Wright became an important informant for them, as well as someone who helped to arrange interviews with other people living in the village and the surrounding area. Shortly after their arrival in Toco she introduced them to Selina Washington, a nurse, originally from Barbados, who had lived in Toco for forty years. As their first informants, Wright and Washington became the first people whom we can see engaging with the Herskovitses in the discourse on religions in Trinidad and the question of the Africanity of Trinidadian culture. At first both women tried to distance themselves from things African, and what they saw as "superstition." They both said they had no knowledge of African dancing, or of African religion. When asked to recite Trinidadian folktales, Washington gave the Herskovitses stories she got from "nursery books" and told them she did not know any "Anansi tales," or stories of the West African (and Caribbean) spider trickster figure (Diary 10). Wright also claimed she did not know any Anansi stories, but eventually the Herskovitses were able to collect some from her son (Diary 14). Further, Wright told the Herskovitses she did not believe in jumbies - spirits of the dead that can sometimes be malicious, or be used with malicious intent by obeah practitioners. However, she is clearly the source for the story in Trinidad Village in which a woman who takes three mangos from a deceased person's tree dreams of a man scolding her for stealing his mangos and subsequently becomes sick, and must appease this spirit with food offerings and an animal sacrifice to become well again (Diary 11-12; TV 157-58). One could read these denials as part of a general indifference or hostility to Africa. However, the Herskovitses had only recently hired Wright and been introduced to her friend, and neither of them knew the white anthropologists very well. Certainly they were trying to be helpful, but given the negative connotations of things African for many in Trinidad at that point, distancing themselves from it was probably the safer move.

In her conversations with the Herskovitses about the Spiritual Baptists and recent Spiritual Baptist arrests that had occurred in the area, Wright talked about the importance of tolerance, though she said she did not attend the Baptist church herself. In a note in the Diary, however, M. Herskovits 
wrote that he considered her "a bit too emphatic about it" (Diary 11), that is, he was convinced she most likely had some connection with one of the churches, if she was not herself a member. In discussing Spiritual Baptist practices, specifically what "Shouters" do when they "shout" and "ring the bell," both Wright and Washington "compared this to the ringing of the bell in the Catholic and Church of England services, though they did differentiate between 'ringing' and 'tinkling'" (Diary 11). Wright and Washington's comparison points to the arbitrary nature of the Herskovitses' assignment of Africa as the origin for such a generic set of practices (bell ringing, "shouting"). Given how roundly demonized and othered the "Shouters" were, their comparison of the Spiritual Baptists with mainstream Christianity (and the religions of the European elites) in the context of Toco was as highly contentious as the kind of comparative work the Herskovitses were doing there. Wright and Washington searched out other available models, examples, or patterns with which to think through and assess Spiritual Baptists' practice that did not have the negative valences that the Herskovitses' Africa had. The general assessments by the colonial elites, and also many in the general population, regarding "Shouter" Baptist practices were negative, ranging from ridiculous to chaotic, obscene, devil worship, or worse. The argument that these women were making here, by contrast, was that these practices were ordinary and comprehensible, that what the Spiritual Baptists were doing was not very different from what many were doing in their own churches (Protestant or Catholic). Rather than simple indifference, Wright and Washington's comparison shows deep interest and thought on the part of Trinidadians, which were, however, different from those of the Herskovitses.

\section{TANGLED STRANDS}

On the night of June 28, 1939, the Herskovitses attended a Spiritual Baptist church service. M. Herskovits wondered in the diary if the chalk designs which they saw on the floor of the Spiritual Baptist church were a Trinidadian version of verver (Diary 22). Verver or veve are elaborate designs done on the ground in ash and cornmeal that correspond to different deities (lwa) in Vodou and are used during rituals addressed to those deities. M. Herskovits's initial move was to account for the chalk markings through the model of verver in Haitian Vodou, a religion that the Herskovitses saw as a "restoration" of "traditional African institutions" (TV 4). What the Spiritual Baptists said about the markings was very different, however. For instance, Josiah Williams, a Toco laborer and member of LaCroix's local Spiritual Baptist group, told the Herskovitses that the chalk markings were the "work of a particular person in the church and has been given him by God when their meaning was revealed" (Notes Book I, 44). This explanation is not one of cultural influence or the 
tracing of historical origins, but an account which appeals to direct revelation by the Holy Spirit to an individual member of the congregation in a dream (a prophetic vision as part of baptism, mourning ground ritual, or spirit manifestation). This sidestepped the question of the Africanity of Spiritual Baptist practice, at least of the kind that the Herskovitses were seeking.

In another statement, Ned, a fisherman and Spiritual Baptist who was fined for permitting "Shouter" services on his land, explained that the chalk designs were culled from material that Spiritual Baptist congregants had received from the De Laurence Company of Chicago, which sold occult magic and science books through mail order. A number of Tocoans participated in the diverse but interrelated discursive traditions of Spiritualism, mesmerism/hypnotism, European magic (called "Kabala" in Trinidad), and the secret wisdom of an Orientalism-inflected "East," adopting and adapting elements from these traditions for their own social-formative projects. Older men in Toco would pool their resources and purchase from the De Laurence catalogue books such as the "Sixth Book of Moses," "Man Know Theyself $[$ sic $]$," the "Heminence [sic] of God," books by Albertus Magnus and books on "Hindu" magic. When the Herskovitses asked about "African language" "magic" books, though, the response from Babb (who identified himself as "part Kramanti, part Hibo") was that "people don' like it, can' read it" (TV 228-29; Notes Book II, 107). When Ned drew examples of the chalk designs for the Herskovitses, he included a mark that M. Herskovits identified as a sign from the zodiac. This in some way changed Herskovits's mind about the analogy of Vodou, prompting him to write in his diary: "Involved stuff, this, with so many different strands tangled into it that one almost despairs of getting it straightened out" (Diary 60). In a later interview, Ned said that the work of the De Laurence Company was itself "correct Baptist;" that "They are taught in the Spirit" (Notes Book II, 72; TV 229). Again, one could see this explanation of origins as part of an indifference to Africa (such as Babb's description of the rejection of "African language" magic books), or as an avid interest in something else, evidence of what even the Herskovitses eventually recognized to be a significant discursive and practical source from which Spiritual Baptists (and others in Trinidad) drew, one strand among many.

The Spiritual Baptist Ned, who had had trouble with the police because of his affiliation with and support for the "Shouters," thus familiarized and rendered intelligible Spiritual Baptist practices by making connections and drawing comparisons to widespread and popular "magic" materials and practices which came to the Caribbean from Europe and other parts of the Americas. In this conversation Ned not only explained the origins of the chalk marks with reference to the De Laurence Company, but also reversed the flow of influence, making the De Laurence Company a "Baptist," and therefore Christian, enterprise (rather than making Spiritual Baptist practice a result of the influence of an American magic mail order catalogue). The 
idea that De Laurence was "taught in the Spirit" suggests that he learned his esoteric knowledge through prophetic vision or dream, as the Spiritual Baptists do during the mourning ground ritual, when they receive "spiritual gifts" from the Holy Spirit, the same source Josiah Williams gave for the chalk marks. Ned and others' identification of the occult science of the De Laurence Company books as a source for Spiritual Baptist discourse and practice further complicates the account of the Spiritual Baptist movement, demonstrating Spiritual Baptist ingenuity, even as they turn that occult science into "correct" Christian religion. The Spiritual Baptists knitted together strands spun not only from Protestant sources (the explanation of the designs with reference to the Spirit and Christian mythology) and "African" ones (similar to verver's relationship between $l w a$ and design), but from whatever "spiritual" resources were available, whatever they saw as being efficacious, whether Albertus Magnus or "Hindu" magic.

\section{AFRICA AS A MATTER OF SPIRIT}

While the Trinidadians that the Herskovitses interviewed may have seemed to them "indifferent" to their proposed retention of African culture in their daily practice, there was an explicit, though not widespread, expansion of "African race consciousness" among the African Trinidadian middle class and intelligentsia across Trinidad, beginning in the 1920s. This included attempts, on a limited scale, to learn African languages and to validate the history of Africans and African Americans through reference to the work of African American scholars such as W.E.B. Du Bois (Singh 1994:51-52). Further, it is clear from the text of Trinidad Village that at least some poor workingclass Tocoans were also not indifferent to Africa, even if they eschewed Africanity. The Herskovitses themselves reported that the mutual aid society, the United Negro Association, a branch of Marcus Garvey's Universal Negro Improvement Association and African Communities League, was present in the village; and that Garvey himself was popular with Tocoans, as was Haile Selassie, then Emperor of Ethiopia, who was seen as fighting the whites (Italian colonizers) for the control of Africa (TV 263, 265). And a major component of the Spiritual Baptist cosmology and ritual practice involves reference to Africa as a territory accessible through dreams and spirit journeys, a place from which African spirits could come, visit a person undergoing the mourning ground ritual, and possibly possess them. So there were clearly different African Trinidadian social movements and political projects emerging in Trinidad among different class groups around the time of the Herskovitses' visit, and a key component of some of those projects was imagining Africa (past, present, and future). Included among those groups were the Spiritual Baptists, who, according to the Herskovitses, very often eschewed Africa. 
The Herskovitses, however, were much less interested in the types of African projects that attracted the Spiritual Baptists, nor was the Africa that the Trinidadians imagined for the most part the Africa the Herskovitses were interested in. They were looking for "their" Africa, uncovering (or imagining) a particular historico-anthropological West African type that was central to their own project, under which these other imaginings of Africa did not fall. So it may be useful to turn away from "indifference," to interest, which is evident in some of these imagined connections to Africa, to see what role they played in the discourse on religion, the political projects, and struggles for local control of knowledge in Toco. We will do this through an examination of the Spiritual Baptist "Teacher," Ethel Patrick.

There were at least two police raids on Spiritual Baptist meetings and several arrests in Toco, Sangre Grande, and Sans Souci, the area where the Herskovitses were working, around the time when they were in Trinidad. The raid most widely discussed, in part because of the high fines passed down by the judge and the fame of the woman pastor, occurred shortly before their arrival. The Evening News of Thursday, June 1, 1939 reported "Shouters Fined": "Ethel Patrick, known as 'Full of Vigour,"” the leader of the Spiritual Baptist group, was charged for "keeping a 'Shouters' meeting;" the penalty was a 50 dollar fine or two months in jail. The Spiritual Baptist reverend, Eudora Thomas (1987:24), recalls in her memoir that Teacher Patrick and members of her church were picked up for a baptism they performed at a river in Sangre Grande. During the time when the Herskovitses did their work the Patrick case appears to have been a frequent topic and was an opportunity for some in the community to engage in (to use Chidester's term) "frontier comparative religion" (Chidester 1996:2-3).

In Trinidad Village, the Herskovitses wrote that, "Only one elderly woman who lived in the area about Toco identified herself primarily with things African. She called herself 'Yarriba,' and recorded a considerable number of songs in the Yoruban language, which she said she could also speak" (TV 28). The "Yarriba" woman, however, was not the only woman in the diary and notes to identify with "things African" and to speak (after a fashion) an "African" language. But the Herskovitses omitted from the Trinidad Village monograph the incident involving another woman, Teacher Patrick herself. When Ethel Patrick does show up in the Trinidad diary it seems that the Herskovitses, particularly Melville, had an ambivalent relationship with her. Teacher Patrick was from Sangre Grande, not far from Toco (Diary 11). As a woman "Teacher" or Spiritual Baptist leader she was something of a controversial figure (e.g., Notes Book I, 41), though overall in the interviews available from the Herskovitses' papers most people in the area were sympathetic to her and her group, particularly with regard to the arrests and fines. But M. Herskovits was suspicious of her, even though she would become a major 
informant for them on Spiritual Baptist practices, and this suspicion even carried over into her anonymous portrayal in the Trinidad Village monograph. ${ }^{19}$

Of his first impressions of her on their meeting on June 30, M. Herskovits wrote: "As might be expected, we got relatively little out of her except an impression of a very clever woman who senses her opportunities and makes the most of them" (Diary 28). He saw her as someone trying to take advantage of the situation somehow. He wrote that during their discussion with her:

\begin{abstract}
She became interested in our talk of Africa, and began to pull talk in "tongues" which she said was African until we didn't recognize any of the words except a possible single one. She has no sense of the paganism of the African people, but stresses their power, and was delighted when we told [her] about possession, which of course is just what happens when, as she explained, "the spirits come to you and you feel strong and shake and shout." (Diary 29)
\end{abstract}

Here Patrick, unlike many of those with whom the Herskovitses spoke, drew comparison and emphasized similarity between African and Spiritual Baptist practice. When she began to "pull talk in 'tongues," however, they took her to be trying to fool them by pretending to know an actual African language. It is quite difficult to uncover Patrick's intentions here; perhaps she was trying to please the anthropologists, giving them what they wanted and thus gaining the interest of those who might have proved prestigious converts for her. However, given that Teacher Patrick was a Spiritual Baptist, it is not surprising that her contribution to their "talk of Africa" was spoken in tongues. The Herskovitses were looking for examples of African "survivals": stories, music, dance, religious rituals, and languages. What Patrick gave them was a (re)construction of Africa of a different sort. Patrick considered the "language" which she was speaking "African," but it was not a "survival" of a particular African language as the Herskovitses understood it. Rather it was a gift from the "spiritual" territory of Africa, a location in the Spiritual Baptist cosmology. It was, I would argue, also very much evidence of the colonial history of Trinidad. Given their reference to her speaking in tongues, with her obvious interest in "power" and spirit possession, it is likely that Teacher Patrick during this interaction was speaking in tongues in the Spiritual Baptist manner, talking "African language," having been, as the Spiritual Baptists understand it, possessed by a spirit of African origin. This was a demonstration at their home of the Spiritual Baptist practice called

19. The Herskovitses write that the possession state of the anonymous "teacher" of the "Shouter" group they visited "seemed to rob her of none of her awareness of the things around her," suggesting it was faked (TV 221). 
mourning ground, which Spiritual Baptists believed gave practitioners such abilities, and which the Herskovitses explicate in their ethnography.

In Trinidad Village the Herskovitses write that the other major "Shouter" Baptist ritual besides baptism is "mournin' ground," which provides "gifts" of visions, higher powers, and further initiation into the "mysteries" of the group (TV 204). The "Mother" (a ritual title) of the group helps in the "mourning," caring for the initiates along with the "Nurse," and helps to interpret visions, which are the main goal of the mourning ground ritual complex. "Spirits" come during the time of isolation, which can last from days to weeks, and take the initiate, through dream, to the spiritual territories of Africa, India, and China, to learn to talk "African," "Indian," or "Chinese language," have visions of other places and people, saints, and angels, and gain other "spiritual" gifts (TV 205). After the mourning ritual, "The mourner sings or speaks, as he is impelled to do by his spirit" (TV 208). This often includes practitioners being compelled to speak "African" or other tongues. Patrick and the Herskovitses' interaction evinces a clash of conceptions of the relationship between race, religion, and language. Despite Teacher Patrick's claims on Africa, however, speaking "African language" did not count, for the Herskovitses, as evidence of something "African," even though the Herskovitses' reconstructions were theoretical acts of imagination not wholly different from the work of the Spiritual Baptists. The Herskovitses considered Patrick ignorant of Africa, and it is clear that Melville at least never quite trusted the "clever woman," even after receiving more information about Spiritual Baptist cosmology.

Patrick's interest, though, was not particular to Africa. She could just as easily have spoken Chinese or Indian "language," because spirits can come from other lands as well. Spiritual Baptists like Teacher Patrick claim not only an African origin for some of their practices, but, as Patrick explained to the Herskovitses and they report in their monograph, an Indian and Chinese one as well, yet further strands added to the tangle. And such gifts are not limited to language. After dream travel to these territories, meeting with different spirits and beings, the person possessed by a spirit of that place will take on the characteristics, presumed likes and dislikes, ways of eating and dress, etc., of the people from that country. For instance, when someone in the mourning seclusion gets an African spirit, they may ask for kuku, identified as an African cassava dish (TV 205). As ethnographers have reported in the last thirty years or so (for example, Glazier 1983), through such vision narratives and possession performances, at least within the space marked off and authorized by the ritual, people could change their usual tastes and comportment, embodying the religious, gustatory, and sartorial habits of Others, including the incorporation of ritual elements from other religions, such as the use of Hindu ritual paraphernalia and Muslim discourse borrowed from Indian Trinidadian Hindus and Muslims. 
Early on in their trip, M. Herskovits visited the head of the police in Toco and was told that the Afro-Trinidadians were little influenced by the "Hindus [Indians]" or "Coolies," but, rather, that the influence, when there was any, went the other way round (Diary 7; TV 20). Trinidad Village does not mention "Indian" elements in Spiritual Baptist practices, ${ }^{20}$ but the diary and notes contain some evidence of greater mutual exchange than the police officer suggested. The police report from the Patrick case identified, as part of the materials recovered at the scene of the "shouting," a lota, or common brass vessel in India brought to Trinidad by indentured Indians and, in the new context, primarily used as an item in Hindu ritual practice. ${ }^{21}$ The lota, readapted by Spiritual Baptists for their own purposes, was itself already an object readapted by the Indians, transformed from an ordinary vessel in India to a ritual item in Trinidad, a readaptation of a readaptation. Moreover, in an interview in the notes, Ethel Patrick tells the Herskovitses that when a mourner comes from the "track" (or spiritual territory) of India, "we take red paint, paint a post across the hand, paint the nails, toes. Dress with veil. They look fine ... Come back say 'Mohamed,' say 'Allah'” (Notes Book II, 78). Even in 1939, clearly, as is evident today, Spiritual Baptists were reimagining, experimenting with, and incorporating into their own rituals Trinidadian Hindu and Muslim discourse and practice, which had been present on the island since 1845, when Indian indentured laborers were first brought across the ocean to work in the cane fields. None of this, however, made it into the final manuscript of Trinidad Village. Nor did the Herskovitses ever unpack the "Hindu" magic books from the De Laurence Company mentioned above, that Ned and other Spiritual Baptists used and that refer us to broader European, Indian, and African American attempts to reimagine, readapt, and incorporate "the mysteries of the East," perhaps along the lines of the Theosophical tradition. The fact that Herskovitses ignored or dismissed Spiritual Baptists' use of Indian material, Muslim and Hindu, may have been due to their focus on "Africanisms," but also perhaps to their distrust of Patrick and of the postulated "spiritual" sources of that "Indian" material.

The prophetic dreams of the mourning ground, in which initiates narrated routes through the Spiritual Baptist cosmos, as well as the resulting "spiritual gifts," were part of strategies for dealing with the situation of colonial Trinidad, mapping out an emerging world system as it related to the lives and histories of peoples at the grassroots in Trinidad. Spiritual Baptist visioning techniques seem to imagine something like what Arjun Appadurai (1996:33) called "cultural flows." Drawing upon the materials made avail-

20. Although they do mention that a "Hindu" woman and her child visited one of the Spiritual Baptist services they attended, but left before the service's end (TV 219).

21. A copy of the Patrick case is included among the Herskovits papers in Folder 105 held at the Schomburg Center. 
able through the globalizing trends of the free flow of unfree labor from across the Americas, West and Central Africa, and South and East Asia the meshing and clashing of newly formed ethnoscapes, ideoscapes, and mediascapes, including Christianity, (neo)African traditions, mail-order Western Esotericism, secret fraternal practices, Caribbean Hinduism and Islam - the Spiritual Baptists endeavored to rethink and recode their location on the bottom rung of society and at the economic margins of their context.

Following a history of forced removal from the material land of Africa, thrown together with other unfree laborers, peasants, and colonized subjects from India and China, the Spiritual Baptists could use their mourning ground prophecies to rework colonial histories and recode colonial hierarchies, allowing the dream narrator free and instantaneous travel across imperial and national borders, returning to Africa, India, and China as spiritual locations. Through the gifts of the spirits of those locations - new languages (glossolalia), motor patterns, and ritual practices - they could cross racial, ethnic, and religious boundaries that the colonizers regarded as demarcating irreducible, conflicting, and natural racial and religious groups. These experiments with what the colonizers considered other people's practices - assuming the patterns of speech, bodily comportment, tastes, gustatory habits, aesthetics, names of deities, and ritual materials of peoples who were assumed to be self-evidently different and racially, religiously, and aesthetically incompatible - contested colonial essentialisms, and hierarchical difference. Through the imaginings of the mourning ground as a material practice, the Spiritual Baptists could gesture beyond the assertions of British racial science, colonial comparative religion, post-slavery peasantization, and "divide-and-rule" policies, though they could not overcome them. But they were able, through this practice of imagination, through reworking their narratives, bodies, and habits, to engineer new ways of organizing human life.

\section{CONCLUSION}

After doing interviews and participant observation with Shango practitioners in Port of Spain from September 9 through 11, the Herskovitses left Trinidad (Diary 114-15). The ethnography based on their work, Trinidad Village, was published in 1947. Trinidad Village is one of the earliest, if not the earliest, ethnography of the Anglophone Caribbean, and the first ethnography of Trinidadian culture. It also marks the beginning of the modern academic study of religion in Trinidad. The Herskovitses made an important contribution, recording many aspects of the lives, the voices, and the dreams of poor black Trinidadians, and they did so with the aim of uplifting all peoples of African descent in the Americas. While their contributions were important, the Herskovitses' work in Trinidad remains equally important as a document 
allowing the scholar of religion a snapshot of the cultural politics of religions and religion-making in the southern Caribbean. In analyzing the struggles over authoritative knowledge about and appropriate performance of the practices of peoples of African descent in the Caribbean, I have attempted to trace the different uses, by anthropologists, colonizers, and colonized, of the attributions, and denial, of "Africanity" and "religion," in Trinidadian religious discourse and practice, in the fabrication of authenticity and coherence, as part of the continuous processes of identity construction and social formation in colonial Trinidad.

Early colonial anthropology (of which colonial comparative religions were a part) served to define the "racial," "tribal," and "religious" essences of African peoples in the British Americas, which often included asserting the slaves' barbaric African nature and lack of religion. Even after the abolition of slavery, a similar discourse of religion still functioned in the colonies, as is evidenced by the continuation of laws banning obeah, "Bongo" dancing and drumming, and the outlawing of Spiritual Baptist groups in Trinidad. The colonial comparative religion done by police, judges, and legislators in Trinidad defined and helped enforce these laws. To a certain degree, then, the essentializations of the Herskovitses' comparative religion work shared problematic assumptions with a colonial anthropology. While they recorded the value of "Africa," they did not challenge the essentializing baseline assumptions about religion and culture at work. Subaltern comparative religionists in Trinidad also contributed to this in different ways, but challenged it too through a counterdiscourse on religion, speaking their groups in the name of religion and a right to its freedom.

While the historical beginnings of the Spiritual Baptists are unclear, I have tried to trace the politics of origins that was played out in Trinidad at the time of the Herskovitses' fieldwork, as part of the discourse on religion being produced there. Instead of imagining African Trinidadian social formation on the model of surface and depth, though, as the Herskovitses did in their ethnography, I would instead propose returning to M. Herskovits's ad hoc metaphor of the tangled strands. In reading through the Herskovitses' diary and field notes, the totalizing portrayal of indifference among Tocoans which they present was clearly too simplistic. What comes out in their work is that people's opinions were contradictory, but there was evidently a deep interest and much thought on origins (whether African or not). Different people responded differently to the Herskovitses' queries and prompts about African and Trinidadian religions. The scholars' and the locals' proposed sources for Trinidadian discourse and practice ran up against and meshed with one another, in ways that reflected the intermeshing and clashing of their interests. While the Africa that the Herskovitses (re)constructed is useful for understanding religion in a Trinidad village, it was just one strand. The metaphor of the tangled strands helps the scholar to keep in mind the ingenu- 
ity of the Spiritual Baptists' projects of social formation - which draws from Africa (however variously imagined), as well as the Caribbean, Europe, and Asia - an ingenuity conceptualized by the Spiritual Baptists through their cosmology and enacted through the "gifts" from the spirits of other lands.

\section{REFERENCES}

APPADURAI, ARJUn, 1996. Modernity at Large: Cultural Dimensions of Globalization. Minneapolis: University of Minnesota Press.

BARON, RoBert, 2003. Amalgams and Mosaics, Syncretisms and Reinterpretations: Reading Herskovits and Contemporary Creolists for Metaphors of Creolization. Journal of American Folklore 116(459):88-115.

CARR, ANDrEW, 1989. A Rada Community in Trinidad. Port of Spain: Paria Publishing.

CHIDESTER, DAVID, 1996. Savage Systems: Colonialism and Comparative Religion in Southern Africa. Charlottesville: University Press of Virginia.

COMAROFF, JEAN, 1985. Body of Power Spirit of Resistance: The Culture and History of a South African People. Chicago: University of Chicago Press.

COTHONAY, MARIE BERTRAND, 1893. Trinidad: Journal d'un missionnaire dominicain des Antilles anglaises. Paris: Victor Retaux et Fils.

Cowley, John, 1996. Carnival, Canboulay and Calypso: Traditions in the Making. Cambridge: Cambridge University Press.

Duncan, CAROL B., 2008. This Spot of Ground: Spiritual Baptists in Toronto. Waterloo, Canada: Wilfred Laurier University Press.

EDWARDS, BRYAN, 1819. The History, Civil and Commercial, of the British West Indies, Volume 2. London: G. and W.B. Whittaker.

— \& William Young, 1801. The History, Civil and Commercial, of the British Colonies in the West Indies, Volume 1. London: John Stockdale.

Foucault, Michel, 1990. The History of Sexuality: An Introduction, Volume 1. New York: Vintage Books.

GaUld, Alan, 1992. A History of Hypnotism. Cambridge: Cambridge University Press.

GERSHENHORN, JERRY, 2004. Melville J. Herskovits and the Racial Politics of Knowledge. Lincoln: University of Nebraska Press.

GLAZIER, STEPHEN D., 1980. Pentecostal Exorcism and Modernization in Trinidad, West Indies. In Stephen D. Glazier (ed.), Perspectives on Pentecostalism: Case Studies from the Caribbean and Latin America. Washington: University Press of America, pp. 67-80. 
—, 1983. Marchin' the Pilgrims Home: Leadership and Decision-Making in an AfroCaribbean Faith. Westport CT: Greenwood Press.

—, 1993. Responding to the Anthropologist: When the Spiritual Baptists of Trinidad Read What I Write About Them. In Caroline B. Brettell (ed.), When They Read What We Write: The Politics of Ethnography. Westport CT: Bergin and Garvey, pp. 37-48.

Gomes, AlBerT, 1974. Through a Maze of Colour. Port of Spain: Key Caribbean Publications.

Herskovits, Melville, 1990. The Myth of the Negro Past. Boston MA: Beacon Press. [Orig. 1941.]

—, 1952. Man and His Works: The Science of Cultural Anthropology. New York: Alfred A. Knopf.

— \& FRANCES S. HERSKOVITS, 1947. Trinidad Village. New York: Alfred A. Knopf.

Howe, StePhen, 1993. Anticolonialism in British Politics: The Left and the End of Empire, 1918-1964. Oxford: Clarendon Press.

Huggins, A.B., 1978. The Saga of the Companies. Freeport, Trinidad \& Tobago: HEM Printers.

JACOBS, C.M., 1996. Joy Comes in the Morning: Elton George Griffith and the Shouter Baptists. Port of Spain: Caribbean Historical Society.

JOHN, A. MEREDITH, 1988. The Plantation Slaves of Trinidad 1783-1816: A Mathematical and Demographic Enquiry. Cambridge: Cambridge University Press.

KoSTLEVy, WiLliam, 2010. Holy Jumpers: Evangelicals and Radicals in Progressive Era America. Oxford: Oxford University Press.

LONG, EDWARD, 1972. The History of Jamaica. Vol. 2. New York: Arno Press.

MaCMILlan, W.M., 1938. Warning From the West Indies: A Track for the Empire. Harmondsworth: Penguin Books. [Orig. 1936.]

MCDANIEL, LORNA, 1994. Memory Spirituals of the Ex-Slave American Soldiers in Trinidad's “Company Villages.” Black Music Research Journal 14(2):119-43.

MintZ, SIDNEY W. \& RichARD PRICE, 1992. The Birth of African-American Culture: An Anthropological Perspective. Boston: Beacon Press.

Monroe, John WARne, 2008. Laboratories of Faith: Mesmerism, Spiritism, and Occultism in Modern France. Ithaca NY: Cornell University Press.

NePtune, Harvey R., 2007. Caliban and the Yankees: Trinidad and the United States Occupation. Chapel Hill: University of North Carolina Press.

Owen, Alex, 1989. The Darkened Room: Women, Power, and Spiritualism in Late Victorian England. Chicago: University of Chicago Press. 
PALMiÉ, StePHAN, 2000. Ackee and Saltfish vs. Amalá con Quimbombó?: A Note on Sidney Mintz' Contribution to the Historical Anthropology of African American Cultures. Journal de la Société des Américanistes. 591(2):89-122.

—, 2002. Wizards and Scientists: Explorations in Afro-Cuban Modernity and Tradition. Durham NC: Duke University Press.

PATON, DiAnA, 2009. Obeah Acts: Producing and Policing the Boundaries of Religion in the Caribbean. Small Axe 13(1):1-18.

PRICE, RICHARD, 2008. Travels with Tooy: History, Memory, and the African American Imagination. Chicago: University of Chicago Press.

— \& SALLY PRICE, 2003. The Roots of Roots or, How Afro-American Anthropology Got its Start. Chicago: Prickly Paradigm Press.

SCOTT, DAVID, 2009. That Event, This Memory: Notes on the Anthropology of the African Diasporas in the New Word. Diasporas 1:261-84.

SENSBACH, JON, 2011. Slaves to Intolerance: African American Christianity and Religious Freedom in Early America. In Chris Beneke \& Christopher S. Grenda (eds.), The First Prejudice: Religious Tolerance and Intolerance in Early America. Philadelphia: University of Pennsylvania Press, pp. 95-217.

SHAW, ROSALIND, 1990. The Invention of "African Traditional Religion." Religion 20: $339-53$.

Simpson, GeORge EATON, 1964. The Acculturative Process in Trinidadian Shango. Anthropological Quarterly 37(1):16-27.

—, 1966. Baptismal, "Mourning," and "Building" Ceremonies of the Shouters in Trinidad. Journal of American Folklore 79:537-50.

SingH, Kelvin, 1994. Race and Class Struggles in a Colonial State: Trinidad 19171945. Alberta, Canada/Mona, Jamaica: University of Calgary Press.

StARK, JAMES HENRY, 1902. Stark's Jamaica Guide: Containing a Description of Everything Relating to Jamaica Including its History, Inhabitants, Government, Resources, and Place of Interest to Travellers. Boston: J.H. Stark.

ThOMAS, EUdorA, 1987. A History of the Shouter Baptists in Trinidad and Tobago. Ithaca NY: Calaloux Publications.

Trotman, DaVid V., 2003. Africanizing and Creolizing the Plantation Frontier of Trinidad, 1787-1838. In Paul E. Lovejoy \& David V. Trotman (eds.), Trans-Atlantic Dimensions of Ethnicity in the African Diaspora. London: Continuum, pp. 218-39.

Underhill, EDWARD BEAN, 1862. The West Indies: Their Social and Religious Condition. London: Jackson, Walford, and Hodder.

Vertovec, SteVen. Ethnic Distance and Religious Convergence: Shango, Spiritual Baptist, and Kali Mai Traditions in Trinidad. Social Compass 45(2):247-63. 
WILLIAMS, JOSEPH J., 1932. Voodoos and Obeahs: Phases of West India Witchcraft. New York: Dial Press.

Winter, Alison, 1998. Mesmerized: Powers of Mind in Victorian Britain. Chicago: University of Chicago Press.

WoOD, DONALD, 1968. Trinidad in Transition: The Years after Slavery. London: Oxford University Press.

Yelvington, KeVIn A., 2001. The Anthropology of Afro-Latin America and the Caribbean: Diasporic Dimensions. Annual Review of Anthropology 30:227-60.

Zane, Wallace W., 1999. Journeys to the Spiritual Lands: The Natural History of a West Indian Religion. New York: Oxford University Press.

ALEXANDER ROCKLIN

History of Religions

University of Chicago

Chicago IL 60647, U.S.A.

<arocklin@uchicago.edu> 